\title{
The Lake Biotic Index (LBI): an applied method for assessing the biological quality of lakes using macrobenthos; the Lake Châlain (French Jura) as an example
}

\author{
V. Verneaux, J. Verneaux, A. Schmitt, C. Lovy, J.C. Lambert
}

Laboratoire de Biologie Environnementale EA 3184 USC INRA, Institut des Sciences et Techniques de l'Environnement (ISTE), Place Maréchal Leclerc, 25030 Besançon cedex. E-mail : valerie.verneaux@univ-fcomte.fr, jean.verneaux@univ-fcomte.fr

\begin{abstract}
The paper proposes a new biological method for assessing the quality of lakes. It is based on the comparison of littoral and profundal macroinvertebrate communities sampled in soft sediments. Two depths were sampled: one at the littoral zone $(\mathrm{Z} \ell=$ $2 \mathrm{~m}$ ) to define a littoral index $(\mathrm{B} \ell)$ related to the biogenic potential of the lake (quantitative data), the other at the deep zone $(Z f=0.66 \mathrm{Zmax})$ to define a taxonomic deficit index (Df ) connected with the quality of the water-sediment interface in deep zone (qualitative data). These two indexes were combined in a Lake Biotic Index (LBI), with a range from 0 to 20 , which gives an evaluation of the biogenic capacity of a lake to the development of macroconsumer communities. Using the $\mathrm{B} \ell$ and $\mathrm{D} f$ values any lake can be plotted on a typological graph which is helpfull to characterize lakes both quantitatively (oligo- to polybiotic) and qualitatively (eu- to dysbiotic). Lake Châlain (French Jura) is presented as an example of the method application with its macrofauna and the index calculation. Then, this lake was included in the typological graph with nine other French lakes studied using the same method. Each lake, characterized by its B $\ell$, Df and LBI values, can be compared to the others in a typological scheme. The proposed indexes are discussed and bases for interpretation of the results are presented. The proposed classification of lakes gives an evaluation of their biogenic capacity concerning macroconsumers and can be usefully compared with other classifications, especially with trophic and sediment types, in functional studies as well as in lake diagnosis, in the context of the Water Framework Directive (Directive 2000/60/CE).
\end{abstract}

Keywords : lakes, macroinvertebrates, biotic index, typology, Water Framework Directive.

\section{Introduction}

At the present day, most of the biological method for lake monitoring is based on their trophic level definition through analyses of nutrient concentrations and/or pelagic primary producers (Vollenweider \& Kerkes 1982) or through analyses of consummer communities (Oligochaeta, Diptera Chironomidae, Fishes) which characteristics are then considered as a trophic level result (Saether 1979, Wiederholm 1980, Lang \& LodsCrozet 1997). But the European Parliament and Council (Directive 2000/60/CE) has stated that the member states have to reach before 2015 the good ecological status of the surface waters. This status has been defined as a result of the structure and the functionning of the ecosystems. Moreover, an European Commission about criteria for identification of freshwater eutrophi- cation enlighted the great difficulty to define largely applicable threshold values of nutrient concentration and primary production because their impact on consummer communities depends on the considered ecosystem (Premazzi \& Cardoso 2001). Some authors have also reported a discrepancy between profundal Chironomid associations and food available in lakes (Rieradevall \& Prat 1991, Real \& Prat 1991). It appears that there is a need of new biological methods offering more synthetical descriptors abble to reflect the ecological status of lakes and not only their tophic level.

Studies on twelve French lakes have underlined the importance of the bathymetric taxonomic deficit (Verneaux et al. 1993 a,b, Verneaux \& Aleya 1998 a,b) in the biological differenciation of lakes. The decrease in macrobenthic biodiversity with increasing depth is a 
feature common to lacustrine ecosystems (Macan 1970, Brinkhurst 1974, Jónasson 1996) but few works deal with the comparison of different depth distribution patterns, including taxonomic richness as a means of lake differenciation (Parrish \& Wilhm 1978, Lindegaard 1979, Mouthon 1993, Verneaux et al. 1993 a, Verneaux \& Aleya 1996, 1998 a).

The paucity of relatively simple methods based on macrobenthos to assess lakes integrity and functionning led us to propose a new applied method based on benthic invertebrates, in reference to its potential usefulness in the context of the Water Framework Directive (Directive 2000/60/CE).

\section{Material and methods}

\section{Outlines of the applied method}

The questionable significance of comparing macroinvertebrate communities from different habitat types, and deep fauna from lakes which have different maximal depths, argues for the use of a comparative analysis based on relative depth (proportional to the maximal depth, i.e. $0.66 \mathrm{Zmax}$ in the proposed applied process) and for the sampling of the sole soft sediment which constitutes the common habitat to the different depths and lakes (Verneaux et al. $1993 \mathrm{a}, \mathrm{b}$ ). This process allows to avoid the great variability of the littoral fauna induced by the heterogeneity of habitat mosaics, especially by substrates and macrophytes (Verneaux et al. 1993 a, Weatherhead \& James 2001). Moreover, the difficulty in species identification from macrobenthic larvae and the doubtful use of pupal exuviae in depth distribution studies (Verneaux \& Verneaux 2002) argue for the use of practical taxonomic units, generally the genus.

A preliminary method, including four, then three and finally two sampling depths, was tested in ten French lakes from 1990 to 2003 (Fig. 1, Table 1). The descriptors which figure in the Table 1 are required for the comments but detailed physical, chemical and biological data can be found in previous works (DIREN et al. 1979-1988, Verneaux et al. 1987, Verneaux et al. 1991, Verneaux et al. 1995, Verneaux \& Aleya 1998 a,b, Verneaux \& Verneaux 2002). The results obtained using successive simplified processes have produced the proposed field method.

\section{The applied method}

\section{Sampling period}

To minimize the effect of seasonal variation in abundance due to the emergence of insects, the sampling period, which followed ice melt and overurn, took place in early spring (Wiederholm 1980). In temperate Middle Europe, this homothermic period $\left(7-8^{\circ} \mathrm{C}\right)$

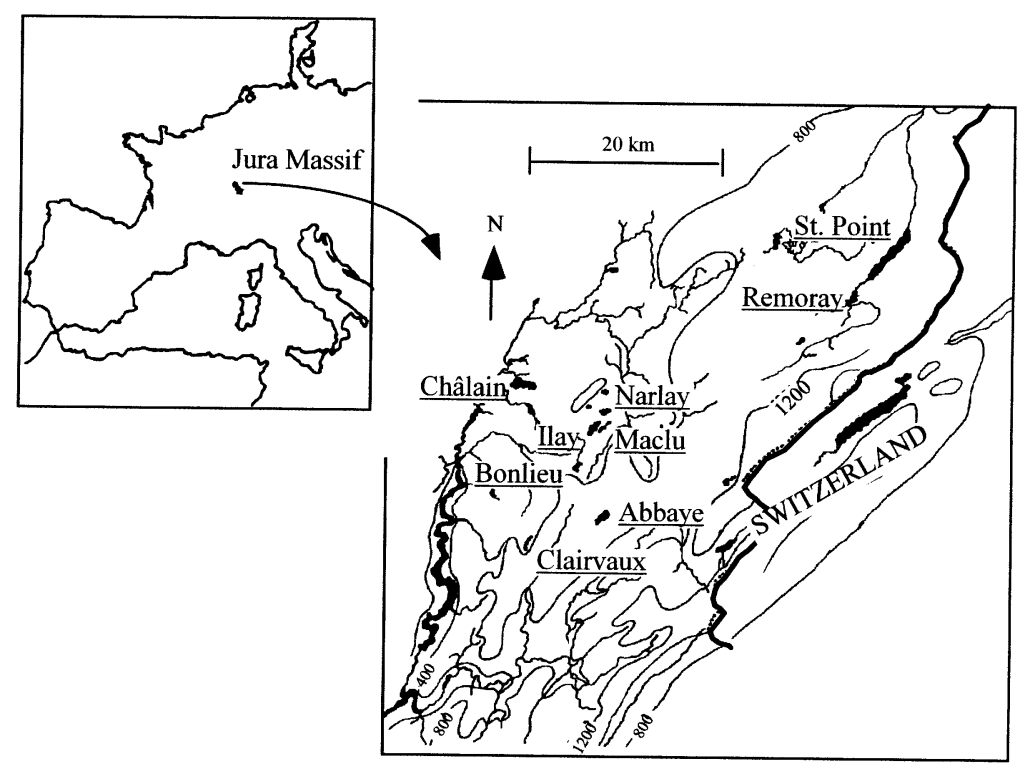

Fig. 1. Geographical location of the ten French lakes. 
Table 1. Main characteristics of the 10 French lakes. Ab : Abbaye, An : Annecy, Bo : Bonlieu, Ch : Châlain, $\mathrm{Cl}$ : Clairvaux, II : Ilay, Ma : Maclu, Na : Narlay, Re : Remoray, Sp : St. Point. L $\boldsymbol{~ : ~ l e n g t h ~ o f ~ t h e ~ l i t t o r a l ~ i s o - ~}$ bath $(2 \mathrm{~m}), \mathrm{L} f$ : length of the deep isobath $(0.66 \mathrm{Zmax}), \mathrm{n}:$ number of samples in littoral $(\mathrm{n} \ell)$ and in deep (nf) zones, $\mathrm{C}$ : conductivity, TOC : Total Organic Carbon, $\mathrm{dw}=$ dry weight, deep water : at $0.66 \mathrm{Zmax}, \mathrm{IV}-\mathrm{X}$ : April to October.

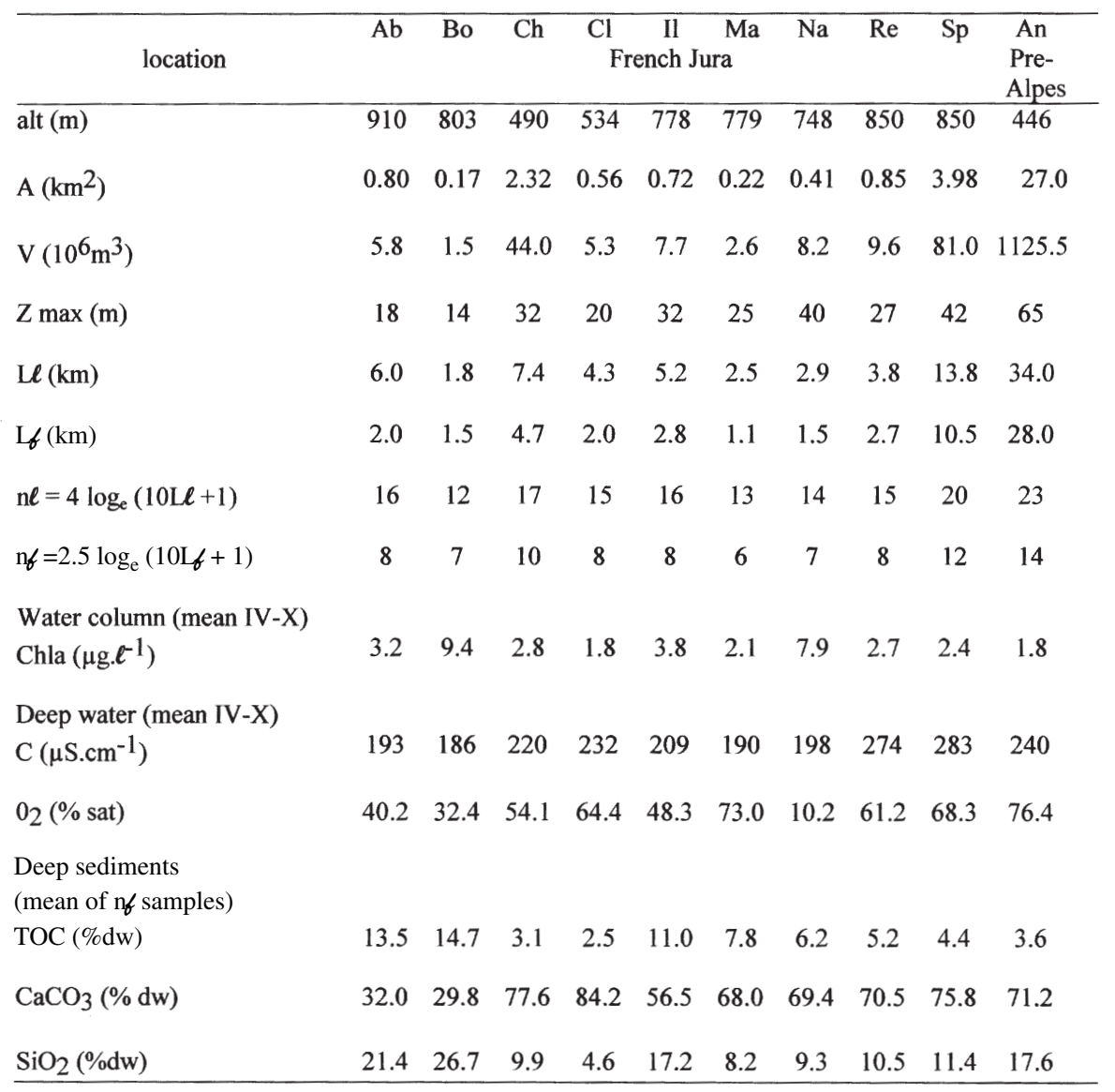

which varies depending on year and altitude, occurs between March and May. Macroinvertebrates were sampled in soft sediment only with an Ekman grab which has been modified by adding two side-overloads and a bottom plate to limit the penetration of the grab in sediment. The modified grab works as a square corer and thus samples the top five centimeters of sediment which contain most of the macrofauna (bioturbation stratum). The sediment was sieved through a $250 \mu \mathrm{m}$ mesh net and the remaining material was preserved in $5 \%$ formalin, transported in ice-boxes and stocked in a refrigerator.

\section{Number of samples and distribution in the lake}

Two depths were sampled; one at the littoral zone $(\mathrm{Z} \ell=2 \mathrm{~m})$, the other in deep zone, at a depth $\mathrm{Z} f$ proportional to the maximum depth (Zmax) of each lake - $(\mathrm{Zf}$ $=0.66 \mathrm{Zmax}$, relative depth).

The number of sites per depth (n) was relative to the length $(\mathrm{L}, \mathrm{km})$ of each isobath (Table 1$)$. For $\mathrm{Z} \ell: \mathrm{n} \ell=$ $4 \log _{\mathrm{e}}(10 \mathrm{~L} \ell+1)$ and for $\mathrm{Z} f: \mathrm{n}_{f}=2.5 \log _{\mathrm{e}}(10 \mathrm{~L} f+1)$. Sites numbers were adjusted at the superior point. The proposed formula for $\mathrm{n}$ calculation have been established to obtain a little more samples than the number of samples required to the stabilisation of the taxon 
richness following the Gaufin's method (Gaufin et al. 1956). For small lakes, the minimum number of samples was fixed at 4 for each isobath. Two samples were cored from each site and pooled together yielding a site sample of $1 / 20 \mathrm{~m}^{2}$ - area and $1 \mathrm{dm}^{3}$ - volume. Sampling sites were distributed clockwise on the two isobaths in accordance with common transects complemented by intercalated sites on the $Z \ell$ isobath. The shores with steep slopes, where isobaths would to be too close, were avoided (Fig. 2). Further details were given in Verneaux et al. (1987, $1993 \mathrm{a}, \mathrm{b})$.

\section{Laboratory procedure}

Macroinvertebrates were hand-sorted at $10 \mathrm{X}$ magnification and identificated at a genus level except for Diptera other than Chironomidae (family), Nematoda (phylum) and Oligochaeta for which three groups have been identificated (Tubificidae with and without hair setae, other Oligochaeta). The individuals from the deep samples were not counted but, to aid in interpreting the results, their abundance was estimated: less than 100 (present, +), from 100 to 500 (abundant, O) and higher than 500 (very abundant, $\bullet$ ). The individuals from the littoral samples were counted and the density of each taxa was expressed in number of individuals per $\mathrm{m}^{2}$ (de, Table 3 ). The occurrence of each taxonomic unit, generally the genus, was specified for the littoral isobath (\% occ., Table 3 ).

\section{Lake Biotic Index (LBI) assessment}

For each isobath, all taxa were listed together. The density of each taxon was derived from the addition of all the individuals collected in each sampling site (Table 3). Five descriptors and two indexes were used to determine the LBI value. The symbols $\ell$ and $f$ were used respectively for littoral and deep zones.

- ve: littoral taxonomic richness = number of taxa collected at $\mathrm{Z} \ell(2 \mathrm{~m})$.

$-\mathrm{d} \ell$ : littoral density $=$ number of individuals $/ \mathrm{m}^{2}$ at $\mathrm{Z}$.

- vf: deep taxonomic richness $=$ number of taxa collected at $\mathrm{Zf}(0.66 \mathrm{Zmax}$.).

- $\mathrm{B} \ell$ : littoral biotic index $=(\sqrt{ } \mathrm{v} \ell)\left(\log _{\mathrm{e}} \mathrm{d} \ell\right)$

- $\mathrm{k}$ : corrective coefficient of the taxonomic loss from $\mathrm{Z} \ell$ to $\mathrm{Z} / \mathrm{k}=(0.033 \mathrm{v} \ell)+1$

- qe: littoral fauna quality index - see Table 2

- Df: taxonomic deficit index $=\sqrt{\frac{k \cdot v f}{v \ell} \cdot q \ell}$

- LBI : Lake Biotic Index $=2.5 \sqrt{ }$ (Be.Df) with $0 \leq$ $\mathrm{LBI} \leq 20$

In the $\mathrm{D} f$ index the $\mathrm{v} f / \mathrm{v} \ell$ ratio was inflected by the $\mathrm{k}$ coefficient in order to obtain relative, comparable $\mathrm{D} f$ values (Verneaux et al. 1993 a), because the bathymetric loss of taxa depends on the littoral taxonomic richness. A littoral fauna quality index (q ) has been included in Df because lakes with little loss of taxa from lit-

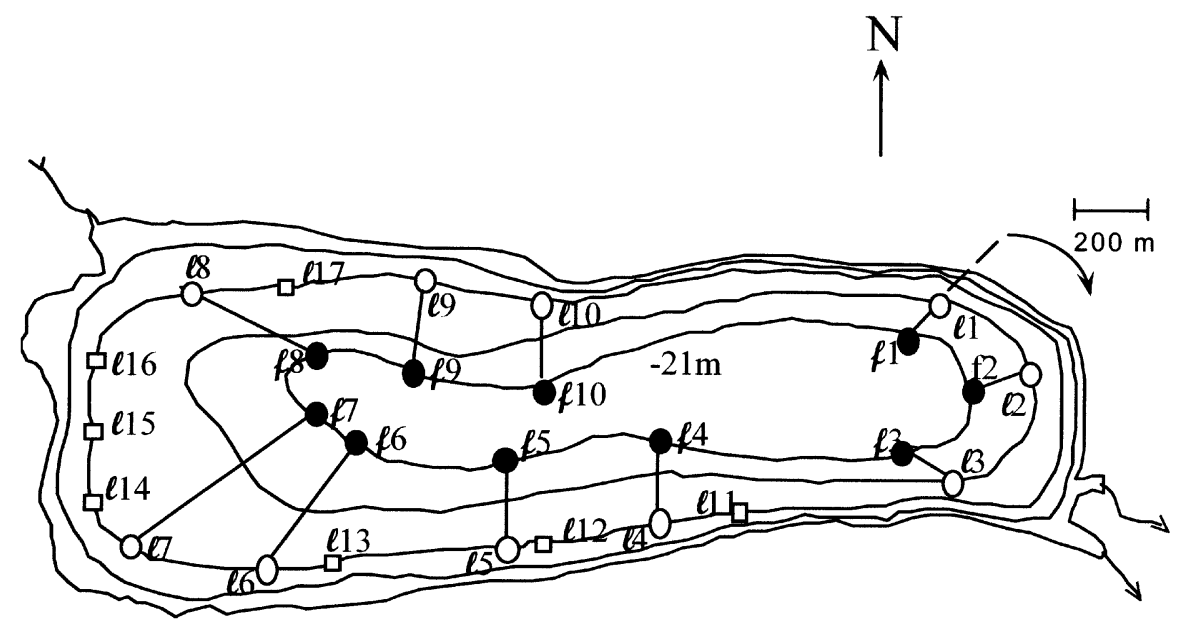

Fig. 2. Lake Châlain : location of the 27 sampling sites on the isobaths. $\mathrm{n} \ell=17$ at $Z \ell, \mathrm{n} f=10$ at $Z$ f,$Z \ell=2 \mathrm{~m}$, $Z f=21 \mathrm{~m}$. $0: \ell 1$ to $\ell 10$, on transects at $Z \ell, \bullet: \& 1$ to $f 10$, on transects at $Z \&, \square: \ell 11$ to $\ell 17$, added littoral sites. 
Table 2. The quality index (qe) of indicator taxa in the littoral zone of lakes. Taxa are graded downwards in increasing order of tolerance level (Verneaux et al. 1993 b, Verneaux 1996, Verneaux \& Aleya 1996, Verneaux \& Aleya 1998 a,b). Ground works : Brundin 1949, Saether 1979, Lafont et al. 1991, Mouthon 1993.

\begin{tabular}{|c|c|}
\hline $\mathrm{q} \ell$ & Taxa sampled at $Z \boldsymbol{\ell}(2 \mathrm{~m})$ with occurrence $\geq 50 \%$ of $\mathrm{n} \boldsymbol{\ell}$ sampling sites \\
\hline 1.0 & Ephemera-Paratendipes - Heterotrissocladius -each genus of Plecoptera \\
\hline 0.9 & $\begin{array}{l}\text { each genus of Trichoptera and Ephemeroptera except Ephemera and } \\
\text { Caenis }\end{array}$ \\
\hline 0.8 & $\begin{array}{l}\text { each genus of Diamesinae and Orthocladiinae except Cricotopus (lato } \\
\text { sensu) and Heterotrissocladius, each genus of Tanytarsini except }\end{array}$ \\
\hline 0.7 & $\begin{array}{l}\text { Cladotanytarsus, Paratanytarsus andTanytarsus } \\
\text { each genus of Tanypodinae except Procladius and Tanypus, each genus } \\
\text { of Chironomini except Paratendipes, Dicrotendipes, Glyptotendipes } \\
\text { Tribelos and Chironomus }\end{array}$ \\
\hline 0.6 & $\begin{array}{l}\text { Sialis, Pisidium, Cladotanytarsus, Paratanytarsus, Tanytarsus, } \\
\text { Prodiamesinae }\end{array}$ \\
\hline 0.5 & $\begin{array}{l}\text { Caenis, Tanypus, Dicrotendipes, Glyptotendipes, Tribelos, Cricotopus } \\
\text { (lato sensu) }\end{array}$ \\
\hline 0.4 & Chironomus, Procladius \\
\hline 0.3 & Oligochaeta except Tubificidae \\
\hline 0.2 & Chaoborus - Tubificidae without hair setae \\
\hline 0.1 & Tubificidae with hair setae, Nematoda \\
\hline
\end{tabular}

toral to deep zones may be either of high biological quality, or on the contrary, highly polluted. In the latter case their littoral fauna contains only tolerant taxa, leaving from the littoral to the profundal zones. The q $\ell$ values of indicator taxa, which decrease when their levels of tolerance increase, are specified in Table 2 . In non or slightly-polluted lakes the q $\ell$ values are close to 1 . The indicator taxon used to attribute $\mathrm{q} \ell$ is the less tolerant taxon collected in a minimum of half of the littoral samples (threshold occurrence $=50 \%$, Table 3).

The $\mathrm{B} \ell$ formula follows from the linear biodiversity gradient obtained using the square root of the taxonomic richness and the natural logarithm of the density (Verneaux et al. 2003).

\section{Typological graph: a LBI interpretation assistance}

Any lake can be plotted on a rectangular graph in which the co-ordinates are respectively the $\mathrm{B} \ell$ and and Df values (Fig. 3). This graph allowed to appreciate the lake biogenic quality through two levels of interpretation. One is quantitatif from oligo- to polybiotic lakes, the other is qualitatif from eu- to dysbiotic lakes. These two levels of interpretation defined four poles: The oligo-eubiotic pole is indicative of lakes with low biogenic potential (low $\mathrm{B} \ell$ ), related to poorly mineralized water, which present a good preservation of taxa in deep zone (high $\mathrm{D}_{f}$ ) related to high oxygen and poor organic matter contents in deep sediments (Verneaux et al. 1995, Verneaux \& Aleya 1998 a). At the opposite, the poly-dysbiotic pole is indicative of lakes with high biogenic potential (highly mineralized) but with low oxygen and high organic matter contents in deep zone. A polyhumic lake, with dystrophic features, is plotted close to the oligo-dysbiotic pole and a well mineralized lake without $\mathrm{O}_{2}$ deficit and without organic matter accumulation is of the poly-eubiotic type. A lake plotted near the center of the graph is meso-merobiotic.

\section{Results}

The detailed Lake Châlain LBI calculation is given as an example of the method application but the LBI have been applied, at the present day, in ten french lakes (Table 1). More detailed physical, chemical and biological data have been specified in DIREN et al. 1986 a, Verneaux et al. 1987, Verneaux \& Aleya 1998 a. 
Table 3. Taxon list of Lake Châlain (French Jura). + : present $(\mathrm{n}<100)$, o : abundant $(100 \leq \mathrm{n}<500), \square$ : very abundant $(\mathrm{n} \geq 500), *$ : indicator taxon, \% occ : occurrence in littoral zone, d $\ell$ : density in littoral zone (ind $\left./ \mathrm{m}^{2}\right), \mathrm{Z} \ell$ : deep isobath $(\mathrm{Z} \ell=0.66$ Zmax).

\begin{tabular}{|c|c|c|c|}
\hline Taxa & $\%$ occ. & $\mathrm{d} \ell$ & Zf \\
\hline \multicolumn{4}{|l|}{ Trichoptera } \\
\hline Athripsodes & 24 & 16 & \\
\hline Ecnomus & 12 & 6 & \\
\hline Mystacides & 12 & 7 & \\
\hline Phryganea & 18 & 19 & \\
\hline \multicolumn{4}{|l|}{ Ephemeroptera } \\
\hline Ephemera* & 53 & 20 & \\
\hline Caenis & 6 & 2 & \\
\hline \multicolumn{4}{|l|}{ Coleoptera } \\
\hline Elmis & 6 & 2 & \\
\hline \multicolumn{4}{|l|}{ Megaloptera } \\
\hline Sialis & 18 & 6 & \\
\hline \multicolumn{4}{|l|}{ Diptera } \\
\hline Ceratopogonidae & 70 & 42 & + \\
\hline \multicolumn{4}{|l|}{ Chaoboridae } \\
\hline Chaoborus & & & + \\
\hline \multicolumn{4}{|l|}{ Chironomidae } \\
\hline \multicolumn{4}{|l|}{ Orthocladiinae } \\
\hline Nanocladius & 12 & 5 & \\
\hline Paracladius & 6 & 2 & \\
\hline Psectrocladius & 24 & 12 & \\
\hline \multicolumn{4}{|l|}{ Tanypodinae } \\
\hline Ablabesmyia & 53 & 80 & + \\
\hline Pentaneurini $x$ & 12 & 25 & + \\
\hline Procladius & 47 & 78 & + \\
\hline Tanypus & 12 & 4 & \\
\hline \multicolumn{4}{|l|}{ Tanytarsini } \\
\hline Cladotanytarsus & 76 & 497 & + \\
\hline Constempellina & 6 & 2 & + \\
\hline Paratanytarsus & & & + \\
\hline Rheotanytarsus & 12 & 4 & \\
\hline Tanytarsus & 94 & 672 & o \\
\hline \multicolumn{4}{|l|}{ Chironomini } \\
\hline Cladopelma & 53 & 27 & \\
\hline Chironomus & & & + \\
\hline Cryptochironomus & 41 & 68 & + \\
\hline Cryptocladopelma & 47 & 55 & \\
\hline Demicryptochironomus & 6 & 1 & \\
\hline Dicrotendipes & 18 & 21 & \\
\hline Einfeldia & 12 & 6 & + \\
\hline Endochironomus & 18 & 4 & \\
\hline Glytotendipes & 6 & 1 & \\
\hline Paracladopelma & 6 & 2 & \\
\hline Paratendipes & 35 & 21 & \\
\hline Polypedilum & 70 & 118 & \\
\hline \multicolumn{4}{|l|}{ Mollusca } \\
\hline Pisidium & 70 & 82 & + \\
\hline Bithynia & 6 & 1 & \\
\hline \multicolumn{4}{|l|}{ Oligochaeta } \\
\hline$\neq$ Tubificidae & 18 & 14 & \\
\hline Tubificidae without hair setae & 100 & 671 & $\square$ \\
\hline Tubificidae with hair setae & 59 & 64 & o \\
\hline Nematoda & & & + \\
\hline littoral density (ind./m2) & & 2657 & \\
\hline
\end{tabular}




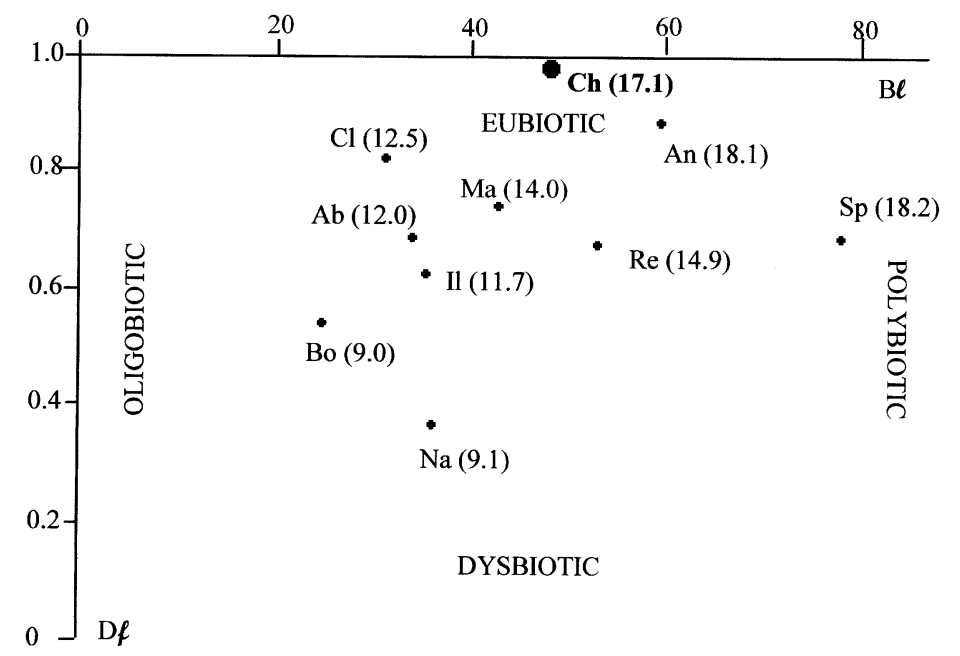

Fig. 3. Distribution of ten French lakes in the typological graph according to the littoral biogenic index $(\mathrm{B} \ell)$ and the taxonomic deficit index $(\mathrm{D} f)$. The LBI values are indicated between brackets. For lake codes see Table 1 legend.

\section{LBI application}

Lake Châlain macroinvertebrates have been sampled in April 1995 at 17 littoral sites (2 m depth) and 10 profundal sites $(21 \mathrm{~m}$ depth) distributed along 10 transects and seven intercalated littoral sites (fig. 2).

\section{Indexes values}

The list of collected taxa (Table 3 ) led to the determination of the 4 descriptors allowing to calculate the $\mathrm{k}$ coefficient, the $\mathrm{B} \ell$ and $\mathrm{D} f$ indexes and the resulting LBI index.

$\mathrm{v} \ell=36, \mathrm{~d} \ell=2657, \mathrm{q} \ell=1.0, \mathrm{v} f=16, \mathrm{~B} \ell=47.3, \mathrm{k}=$ $2.19, \mathrm{D} f=0.98, \mathrm{LBI} / 20=17.1$

\section{Typological graph and comments}

In 1995, Lake Châlain belonged to the meso-eubiotic type (fig 3). In the littoral zone the indicator taxon was Ephemera so that the qe value was 1 . The littoral biotic index value $(\mathrm{B} \ell)$ was medium and the taxonomic deficit was low in the deep zone $(\mathrm{D} f=0.98)$. These biotic descriptors reflect the well-mineralized (conductivity from 175 to $300 \mu \mathrm{S} . \mathrm{cm}^{-1}$ ) calcareous type (mean $\mathrm{CaCo}_{3}$ in sediment $\approx 78 \% \mathrm{dw}$, Table 1 ) of Lake Châlain with good conditions in the deep zone. The lowest $\mathrm{O}_{2}$ values, observed in autumn, at 0.66 Zmax, were close to $4 \mathrm{mg} / \mathrm{l}$, and the organic matter content in the sediment was lower than $5 \% \mathrm{dw}$. The good biogenic values observed in 1995 were underli- ned by the facts that Ephemera was found in more than $50 \%$ of the littoral samples, by the predominance of Tanytarsini in the deep zone, and by the non-proliferation of Chaoborus and Tubificidae with hair setae in the deep zone (Table 3$)$. This chalk lake $\left(\mathrm{CaCo}_{3}\right)$ with Coregonus (Whitefish) and carnivorous species (Perca fuviatilis, Perch and Esox lucius, Pike), is very busy in summer with leisure activities such as sailing, camping and fishing.

\section{Discussion}

The positions of the lakes in the typological graph and the LBI values obtained using the proposed simplified method proved to be close to the ones obtained using more detailed sampling processes (including 3 or 2 relative depths) although a less accurate evaluation of the bathymetric biological changes (Verneaux et al. 1993 a, b, Verneaux et al. 1995, Verneaux et Aleya 1998 a).

The method gives a general biogenic value (LBI) and two indexes ( $\mathrm{B} l$ and $\mathrm{D}$ ) ) which are useful for the explanation of the general index. The LBI scale is based on the maxima and minima values of the used variables observed in the ten lakes studied using the specified sampling method. The proposed method is considered as experimental and further studies may result in modifications of this initial calibration, particu- 
larly that concern the most biogenic arrangements between abundance, taxonomic richness and the list of indicator taxa that could be completed.

Studies on relationships between biological data and environmental variables have shown that the littoral biotic index $(\mathrm{B} \ell)$ was related to trophic potential (conductivity, calcium and nutrients) and that the taxonomic deficit index (Df) was related to the bottom dissolved oxygen and the organic matter content in sediment (Verneaux et al. 1995, Verneaux \& Aleya 1998 a). Many other authors have underlined the main role of these two factors in macrobenthos distribution (Brundin 1951, Johnson \& Wiederholm 1989, Lafont et al. 1991, Real \& Prat 1991, Mouthon 1993). It has been recently shown that dissolved oxygen proved to be limitant for macroinvertebrate biodiversity from $90 \%$ saturation and very limitant from $65 \%$ saturation, and that, for total organic carbon in sediment, a preferendum appeared around $3 \% \mathrm{dw}$ (Verneaux et al. $2003)$. The proposed value ( $\approx 10 \%$ OM in sediment) was considered as an indicator showing the onset of dysbiotic features (Verneaux \& Aleya 1998 a, Verneaux et al. 2003). Dysbiotic lakes can be characterized by a high content of allogenic residual matter in the sediment, without high chlorophyll-a content (Lake Abbaye), or by high residual algal biomass resulting in high nutrient input and high primary biomass (Lake Narlay) or by both (Lake Bonlieu, Table 1).

Because all the low values of the taxonomic deficit index (Df) were related to high values of residual organic matter connected with deep oxygen deficit, these two environmental descriptors were chosen as indicators of the ability of a lake to transfer organic matter up to the consumers. Compared to the trophic classifications using profundal macrobenthos (Saether 1979, Wiederholm 1980, Brodersen \& Lindergaard 1999, Milbrink et al. 2002), these results seem controversial because profundal macroinvertebrate biodiversity depends on factors other than pelagic primary production or nutrient rates. Thus, Lake Annecy (fig. 3) with a high $\mathrm{D}$ f value $(0.88)$ can be classified among lakes having a good depth-related preservation of taxonomic richness reflecting favourable environmental conditions that allows or reflects (or both) a good transfer of organic matter through the food web. This lake with a mean Chl-a close to $2 \mathrm{mg} / \mathrm{m}^{3}$, is oligo-mesotrophic, but shows however a high biogenic capacity (poly-eubiotic lake).

Separated interpretations of the lake biogenic potential $(\mathrm{B} \ell)$ and the lake functional capacity (D\&) seemed of importance since no simple correlation appeared betwen these two lake characteristics (fig. 3). The pro- posed indexes and the typological graph led to assess the resulting biogenic capacity which might be useful both for more accurate functional studies (Verneaux et al. 2002) and for lake diagnosis and lake surveys according to the last European Directive (Directive 2000/60/CE)

\section{Acknowledgments}

Ours thanks to Lois Rose for the improvement of the English text and to reviewers for their useful comments.

\section{References}

Brinkhurst O.R. 1974. - The Benthos of Lakes. Mc. Millan Press Ltd., London, Basingstoke, 182 p.

Brodersen K.P. \& Lindegaard C. 1999. — Classification, assessment and trophic reconstruction of Danish lakes using Chironomids. Freshwat. Biol., 42, 143-175.

Brundin L. 1951. - The relation of $\mathrm{O}_{2}$ - microstratification at mud surface to the ecology of the profundal bottom fauna. Report Instit. Freshwat. Res., 32, 32-42.

DIREN Franche-Comté, CEMAGREF Paris, Lyon \& Laboratoire d'Hydrobiologie de l'Université de Franche-Comté, Besançon 1979-1988 . — EPR Fr. Comté, DIREN (eds). Besançon.

Monographies des lacs du Jura :

- 1979: Les lacs de Saint-Point et de Remoray, 105 p et annexes

- 1982: Le lac de 1'Abbaye, 61 p et annexes

- 1984: Le lac de Clairvaux, 99 p et annexes

- 1985: Les lacs Maclu, 104 p et annexes

- 1986a: Le lac de Châlain, 116 p. et annexes.

- 1986b: Le lac d'Ilay, 95 p et annexes

- 1987a: Le lac de Bonlieu, 97 p et annexes

- 1987b: Le lac d'Etival, 87p. et annexes.

- 1988: Le lac de Narlay, 30 p. et annexes

Gaufin A.R., Harris E.K. \& Walter H.J. 1956. - A statistical evaluation of stream bottom sampling data obtained from three standard samplers. Ecology, 37, 643-648.

Johnson R.K. \& Wiederholm T. 1989. - Classification and indication of profundal macroinvertebrate communities in nutrient poor, oligo-mesohumic lakes in relation to environmental data. Freshwat. Biol., 21, 275-386.

Jónasson P.M. 1996. - Limits for life in the lake ecosystem. Verh. Internat. Verein Limnol., 26, 1-33.

Lafont M., Juget J. \& Rofes G. 1991. — Un indice biologique lacustre basé sur 1'examen des Oligochètes. Rev. Sci. Eau, 4, 253-268.

Lang C. \& Lods-Crozet B. 1997. - Oligochaetes versus chironomids as indicators of trophic state in two Swiss lakes recovering from eutrophication. Arch. Hydrobiol., 139,187-195.

Lindegaard C. 1979. — Bathymetric distribution of Chironomidae (Diptera) in the oligotrophic Lake Thingvallavatn, Iceland. Pages 225-232 in Chironomidae. Ecology, systematics, cytology and physiology. D.A. Murray (eds). Pergamon Press, Oxford, New York, Toronto, Sydney, Paris, Frankfurt.

Macan T.T. 1970. — Biological studies of the English lakes. Longmans, Grennard Co. London, 338 p.

Milbrink G., Timm T. \& Lundberg S. 2002. — Indicative profundal oligochaete assemblage in selected small Swedish lakes. Hydrobiologia, 468, 53-61.

Mouthon J. 1993. — Un indice biologique lacustre basé sur l'examen des peuplements de Mollusques. Bull. Fr. Pêche et Pisc., $331,397-406$. 
Parrish J.H. \& Wilhm J. 1978. - Relationship between physicochemical conditions and the distribution of benthic macroinvertebrates in Arbuckle Lake. The Southwest. Nat., 23, 135-144.

Premazzi G. \& Cardoso A.C. 2001. - Criteria for identification of freshwaters subject to eutrophication. European commission, EIJRC, Ispra, Environment DG, $60 \mathrm{p}$.

Real M. \& Prat N. 1991. - Changes in the benthos of five Spanish reservoirs in the last 15 years. Verh. Internat. Verein Limnol., 24, 1377-1381.

Rieradevall M. \& Prat N. 1991. - Benthic fauna of Banyoles Lake (NE Spain). Verh. Internat. Verein. Limnol., 24, 1020-1023.

Saether O.A. 1979. - Chironomid communities as water quality indicators. Hol. Ecol., 2, 65-74.

Verneaux V. \& Aleya L. 1998 a. - Bathymetric distributions of chironomid communities in ten French Lakes: implication on lake classification. Arch. Hydrobiol., 142, 209-228.

Verneaux V. \& Aleya L. 1998 b. - Spatial and temporal distribution of chironomid larvae (Diptera: Nematocera) at the sediment-water interface in Lake Abbaye (Jura, France). Hydrobiologia, 373-374, 169-180.

Verneaux J., Remy F., Vidonne A. \& Guyard A. 1987. — Caractères généraux des sédiments de 10 lacs jurassiens. Rev. Sci. Eau, 6, 107-128.

Verneaux J., Schmitt A. \& Verneaux V. 1995. — Classification biologique des lacs jurassiens à l'aide d'une nouvelle méthode d'analyse des peuplements benthiques. III. Relation entre données biologiques et variables du milieu. Ann. Limnol., 31, 277-286.
Verneaux V. \& Verneaux J. 2002. - Assessing lake functioning using the macrobenthic community with special reference to Diptera Chironomidae. One subalpine lake (Lake Annecy) as an example. Arch. Hydrobiol., 154, 61-78.

Verneaux J., Verneaux V. \& Guyard A. 1993 a. - Classification biologique des lacs jurassiens à l'aide d'une nouvelle méthode d'analyse de la macrofaune des sédiments. I : variété et densité de la faune. Ann. Limnol., 29, 59-77.

Verneaux J., Verneaux V. \& Guyard A. 1993 b. — Classification biologique des lacs jurassiens à l'aide d'une nouvelle méthode d'analyse des peuplements benthiques. II. Nature de la faune. Ann. Limnol., 29, 383-393.

Verneaux J, Verneaux V. \& Lambert J.C. 2003. — Relationships between macrobenthos, dissolved oxygen and organic matter at the sediment-water interface in ten French lakes. Arch. Hydrobiol., (in press).

Verneaux J., Vidonne A., Remy F. \& Guyard A. 1991. — Particules organiques et rapport $\mathrm{C} / \mathrm{N}$ des sédiments des lacs du Jura. Ann. Limnol., 27, 175-190.

Vollenweider R.A. \& Kerkes J. 1982. — Eutrophication of waters, monitoring, assessment and control. OECD Paris.

Weatherhead M.A. \& James M.R. 2001. — Distribution of macroinvertebrates in relation to physical and biological variables in the littoral zone of nine New Zealand lakes. Hydrobiologia, 462, 115-129.

Wiederholm T. 1980. - Use of benthos in lake monitoring. J. Wat. Polut. Control Fed., 52, 537-547. 